\title{
The Politics of Naming, Misnaming and Renaming in The Trial of Dedan Kimathi (1976) by Ngugi wa Thiong'o and Micere Githae Mugo
}

\author{
Saliou Dione \\ Department of Anglophone Studies, Cheikh Anta Diop University of Dakar, Dakar, Senegal \\ Email address: \\ salioudione@hotmail.com

\section{To cite this article:} \\ Saliou Dione. The Politics of Naming, Misnaming and Renaming in The Trial of Dedan Kimathi (1976) by Ngugi wa Thiong'o and Micere \\ Githae Mugo. International Journal of Literature and Arts. Vol. 6, No. 3, 2018, pp. 44-53. doi: 10.11648/j.ijla.20180603.11
}

Received: June 7, 2018; Accepted: July 6, 2018; Published: August 16, 2018

\begin{abstract}
Ngugi and Mugo's co-authored play, The Trial of Dedan Kimathi (1976), encompasses a vast vision of history and memory in the indigenous war of resistance against British colonialism. The play aims at focusing on the Kenyan masses-led struggle before and after constitutional independence. It intends to give ground to an insightful analysis of the politics of naming, misnaming, and renaming which, indeed, has been used as a way of fashioning and refashioning this part of Kenya's history. To make it through, we will adopt an onomastic approach to further see how the two playwrights engage in (hi)story, historicity and memory (re)construction of the Mau Mau revolution and its leader Dedan Kimathi, and herocism and memoria building, and weave (hi)story and ideology with a view to breaking the psychological and economic bondage of the neo/colonial periods. In so being, it will be possible to point out how the protagonist, Dedan Kimathi, sets at defiance the colonialist's politics of domination and exploitation in the colonial and post-colonial eras.
\end{abstract}

Keywords: (Hi)story, Memory, (Neo)colonization, Trial, Politics, (Re)construction, Resistance

\section{Introduction}

The colonial history of Kenya can be dated back to the Berlin Conference in 1884-1885 when the European colonial powers decided to partition Africa into territories of influence. Sequential from that was the British government's foundation of the East African Protectorate and decision to make of it a settler colony during the period. Consequently, many Indians were 'smuggled' into the country to build the Kenya-Uganda Railway Line and subsequently settled there. Later on, many more of them, who were mainly traders in India, were invited to join. In fact, the years of British colonial rule in Kenya were characterized by punitive economic, social, and political policies. Most outrageous and dehumanizing of these were the apartheization system that resulted in differentiation and otherization that allowed settlers a voice in government while the Africans and Asians had no right to political participation. Because of its politics of racial discrimination, huge fertile land was alienated for white settlement while harsh labor laws were enacted to force the natives to work at low wages on settler farms and public works. However, this race-based scenario led to the emergence of African protest movements. So, members of the Kikuyu, Embu, Meru, and Kamba ethnic groups took an oath of unity and secrecy to fight for their freedom from British rule and snatch back what belonged to them: their land. The Mau Mau Movement emerged with that oath, which embarked the country on its long hard road to national sovereignty. In their muffling and quashing strategies, the British colonialists resorted to the politics of naming, misnaming, and renaming. Consequently, different views about the guerilla struggle emerged. Wunyabari O. Malyoba (1993) regards the rise of the Mau Mau movement as "without doubt, one of the most important events in recent African history" [1]. David Anderson (2005), however, considers Maloba's and similar work to be product of "swallowing too readily the propaganda of the Mau Mau war," [2] noting the similarity between such analysis and the "simplistic" (Anderson, 2005: 10) [3] earlier studies of Mau Mau. This earlier work casts bipolar terms, "as conflict between anti-colonial nationalists and colonial collaborators" (Anderson, 2005: 10). Caroline Elkin (2005)'s 
analysis of the movement has also met similar criticism, as well as being criticized for sensationalism [4].

Therefore, disappointed at the various negative discourses surrounding the Mau Mau revolution and its fighters and also realizing the absence of literature productions by Kenyan writers about the country's struggle for independence, and that the only existing versions are the falsified, biased, and distorted ones by the colonialists, Kenyan playwrights Ngugi wa Thiong'o and Micere Githae Mugo have decided to embark on a discursive struggle of history and memory (re)construction. Since reality is recreatable, they use drama to rename and rebuild an African version of Kenya's historical reality. To this end, in The Trial of Dedan Kimathi (1976), they present a revolutionary play about the Mau Mau insurgency, as first a response to a play written by Kenneth Watene [5], and second as a way of setting at defiance the colonialists' account of this important part of Kenya's history. The two playwrights take it for granted that Watene's play has joined the British in their demonization and falsification of the country's history of the struggle for independence by portraying Dedan Kimathi, the leader of the uprising, as a 'crazy' and 'brutal paranoiac,' rather than as a leader engaged in a continuing struggle against economic and other forms of oppression.

How is the politics of naming, misnaming, and renaming reflected in the history and memory (re)construction of the Mau Mau uprising against British colonial rule in Ngugi and Mugo's drama? What is then the relevance of rewriting about the heroes and heroines of that part of Kenya's history? How are (hi)story and ideology woven to break the psychological and economic bondage of the neo/colonial periods.

Naming, misnaming, and renaming, as central elements in Ngugi and Mugo's co-authored play, provides insight into the constructed and negotiated nature of history, memory, memoria, and identity. Hence, the need to attach an importance to them, to the consequent power of the namegiver, the name-denier, misname-giver and misname-receiver and denier, as well as the role of self-proclaimed voice (s) who articulate ( $\mathrm{s}$ ) narratives. Naming and misnaming being political, they also stem from the characteristics and associated rights linked to renaming.

\section{2. (Hi)story, Historicity and Memory (Re)construction: Re/telling the Mau Mau Revolution}

From the construction of ritual performance, the function of mnemonics, as the process or technique of improving or developing the memory, the formulation of devotional practices, and the creation of commemorative works of art and architecture, memory lies at the convergence or crossroad of history and identity. Faced with the tension between remembering, what to remember and not to remember, reinventing and erasing, Ngugi wa Thiong'o and Micere Githae Mugo inquest into the significance of memory and historicity across their various permutation in the postcolonial imagination. In The Trial of Dedan Kimathi (1976), they interweave memory and images (present and absent) by engaging with and examining the role of drama in the cognitive processes of memory and historicity, in light of the approach by authors, artists, and readers as reflections of their memoria insofar as the playwright, like the historian, cannot study collective memory without taking individual memory into account and vice versa [6]. As made clear by the two authors as early as the preface, the play is not a reproduction of what is termed a reproduction of the farcical trial of Nyeri. It is rather an imaginative recreation of the Mau Mau uprising with their leader Dedan Kimathi in which they trace out the social and economic conditions during colonization. They have designed a three-movement play as first a way of Africanizing drama and second of expressing their opposition to the British history and memory construction and their colonial politics of domination and exploitation. They choose not to respect the classical rule of the three units - time, place, and action - as a way of updating the existing gap in the historical representation by a Kenyan telling of the grandeur, the good deeds, and of the heroic resistance of Kenyan people who were fighting British forces during the colonial period. To this end, the play redefines the role the Mau Mau movement played in gaining Kenya's political autonomy and socio-cultural reidentification.

In fact, the resistance movement traces its origin back to the time when Kenyans and other East African people decided to take up arms and put an end to European colonial rule - the Portuguese forces of conquest, murder and plunder and the British discriminate, grab fertile lands, and exploit the country's natural resources. In this instance, one must not underestimate the impact of the naming, misnaming, and renaming for Africans in general and Kenyans in particular, whose cultures attach an importance to naming so profound that ceremonies are performed to mark it. Colonizers are quick to appropriate that power, while remaining totally oblivion of and insensitive to the implications and consequences of their act. Therefore, Ngugi and Mugo's revisionist strategy enables the reader to imagine the actions of brave men [who] were in the past as if they were present, as writers in a crusade against the representation of the history of the Mau Mau revolution. They delve into the colonial past to engage the reader in a history, historicity, and memory deconstruction and reconstruction processes, asking as early as the preface:

Was the theme of the Mau Mau struggles exhausted in our literature? Had the heroic peasant armed struggle against the British Forces of occupation been adequately treated in our literature? Why was Kenyan Literature on the whole so submissive and hardly depicted the people, the masses, as capable of making and changing history? Take the heroes and heroines of our history: Kimathi, Koitalel, Mekitilili, Mary Nyanjiru, Wiyaki. Why were our imaginative not singing songs of praise to these and their epic deeds of resistance? Whose history and whose deeds were the historians and creative writers recording for our children to read? [7]. 
In their history and memory reconstruction, Ngugi and Mugo seek to draw the reader's attention to the intertextualities and intervisualities in post-colonial Kenya by succinctly explaining how texts, discourse (history and story), and images (characters and setting) can simultaneously recollect the ancient past and reflect the colonial present. They build up a response to colonialist writings about the guerilla and its leader, Dedan Kimathi. The co-authors have understood that the naming and misnaming of place/setting (kenya), and historical events (colonization/Mau Mau revolution) are then the most important expression of power. The uprising resulted from the restrictions placed upon the Kikuyu people, both economically and socially. Despite using repression, the British white settlers made them feel alienated from their own society, thus fueling a feeling of discontent and leaving them with no other alternative than to revolt. According to some members of the Mau Mau, they never referred to themselves as such, instead preferring the military title 'Kenya Land and Freedom Army (KLFA)' [8]. Some publications, such as Fred Majdalany's State of Emergency: The Full Story of Mau Mauc claim it was an engram of Uma Uma, which means 'get out get out' and was a military codeword based on a secret language-game Kikuyu boys used to play at the time of circumcision. For Majdalany, the British simply used the name as a label for the Kikuyu ethnic community without assigning any specific definition [9]. As the movement moved on, a Swahili backronym was adapted, Mzungu Aende Ulaya, Mwafrika Apate Uhuru which means "let the foreigner go back abroad, let the African regain independencec J. M. Kariuki, who was a former Mau Mau detainee during the conflict, states that the British preferred to use the term Mau Mau instead of KLFA as part of their politics of denying the rebellion international legitimacy (Majdalany, 1963: 75). Ngugi and Mugo recall how the British adopted that same politics term in order to counter what they regarded as colonial propaganda [10]. Their view was that the Mau Mau were savage, violent and depraved tribal cult,' an expression of unrestrained emotion rather than reason. For them those people sought to take the Kikuyu people back to the bad old days" before British rule"(Kariuki, 1960: 24).

A variety of causes engendered economic, social, and political tensions in the country, compelling them to mold political goals that would drive out the white settlers and isolate African enemies (Kariuki, 1960: 24). The revolutionaries sought to regain their economic independence that was lost through colonialism [11]. Despite internal divisions, the Mau Mau freedom fighters were bound to each other by hopes of citizenship and bureaucracy [12]. In the debate about their related history, the colonialists like Shaw Henderson in Ngugi and Mugo's play have deployed the tactic of renaming to misname and silence in order to marginalize voices which are making legitimate arguments against the pitfalls and wrong headedness of campaign by British colonizers against the anti-colonial movement. The Dedan Kimathi-led Mau Mau fighters, who have been objected to the modus operandi of Kenyan insurgents, have been labelled, indicted, cracked down, and dismissed. To depoliticize and prevent their movement from gaining more backing at the country-level and international recognition, the British used the Western-inspired name game that obfuscates the real issue in the matter. This politics constituted then a diversion that exposed the renaming-to-misname tactic.

The renaming-to-misname (changing the subject) strategy has been resorted to by colonial advocates to put pro-choice colonial activists on the defensive, a strategy that is tantamount to censorship, division, and resistance so as to prevent any self-affirmation and self-determination attempt. With their divide-and-rule policy, the Mau Mau revolt debate among the Kenya populations polarizes with the shift in the language to articulate it, particularly owing to the entrenched ideological position and profound ethical questions that have been injected into it, the naming and renaming of the combatants as "terrorists" (Ngugi \& Mugo, 1976: 6) on the day of their trial when Waitina, one of the characters, addressing two soldiers stationed at the opposite end of the stage shouted at them, ordering Askari to "cover the streets well and shoot down at bloody terrorists. Sikia?" (Ngugi \& Mugo, 1976: 6). The strategy has also enabled them to pit Kenyan people against each other - pro-Mau Mau against anti-Mau Mau. As a result of their demonizing tactic, the K. A. R (King African Rifles)'s solders in Ngugi and Mugo's drama, as a group non-commissioned African officers fighting against their Kenyan brothers in support of the British colonial agenda, was formed. Because also of that tactic, some detainees like Kimathi's bother, Wambararia, Hungu, Gati, and Gaceru worry that the substance of their lives is draining away and think their primary duty lies with their families. They therefore decide to surrender and confess to British officers like Waitina. Others refuse to accept the British demand that they sully other fighters' reputations by naming those whom they know to be involved in the movement. Colonial official Shaw Henderson plays on some detainees' devotion to their families to make them confess and thus break their allegiance to the Dedan Kimathi-led revolution. Then, the battle behind the wire is not fought between patriotic hard-core Mau Mau and weak-kneed, wavering, broken men like Wambararia, Hungu, Gati, and Gaceru who confess. Both hard-core and soft-core have their families in mind as evidenced by Kimathi's bother who thinks of his aging mother. The British then not only put them against a name they did not call themselves, they also picture them as just 'mentally sick persons' and agitators who want to spread unrest and throw people's minds into confusion.

\section{The Politics of Identity, Herocism and Memoria Building}

The commemoration of individuals and the politics of identity are complex issues, hardly topics that one can scratch their surface. It is through naming and branding of place and 
individuals that people create their identity and politics. The naming and meanings are the most important expression of power as evidenced by Jacques Derrida (Clough, 1998: 24) who argues that naming is a taxonomic strategy and a manifestation of power. Then, Ngugi and Mugo have caught the colonialist in the appropriation of names and histories; he is caught up in the acts of (re)creating reality, history, historicity, memoria, memoryspace, and heroes, and heroines as well as rebranding national post/colonial narratives. This is one of the reasons that makes the writing of The Trial of Dedan Kimathi (1976) both challenging and exciting insofar as it puts [us] through a lot of education in connection with the continuing struggle against economic and other forms of oppression that entail resilience and militancy from the oppressed:

There was no single historical work written by a Kenyan telling of the grandeur of the heroic resistance of Kenyan people fighting foreign forces of exploitation and domination, a resistance movement whose history goes back to the $15^{\text {th }}$ and $16^{\text {th }}$ centuries when Kenyans and other East African people first took arms against European colonial power - the Portuguese forces of conquest, murder and plunder (Ngugi \& Mugo, 1976: ii).

Ngugi-Mugo's play strives to restore the truth about the Kenyan anti-colonial hero Dedan Kimathi, who was portrayed as a 'terrorist' and 'mentally sick person' in the British archives. They make him their central character and, prior to writing the play, they travelled to his homeland for story and history recollections:

Karunaini was right next to Nyandarua Forest and, standing very near the school where Kimathi once taught, we could see the spot where he was finally shot down. The huge trench that the people were once forced to dig by the British forces so as to cut off the villages from the Forests was still visible (Ngugi \& Mugo, 1976: ii).

In the preface, they make an account of their field work after their description of the place where the revolution leader once taught, adding having met a woman who used to be his pupil. This is to substantiate and show the trustworthiness of their stories from which they also display few factual stories as well as one or two conflicting legend (s) about Kimathi as opposed to what the British colonialists reported:

For instance, it is generally assumed that Kimathi fought in the Second "World" War and people have tended to assume that was where he learnt his military skills as well as his skills in making guns. Kimathi never fought in that war. $\mathrm{He}$ evolved his brilliant guerilla tactics and his enormous organizing capacity from the needs of the struggle (Ngugi \& Mugo, 1976: ii).

They proceed with sharing their source material, underscoring that Karari Njama's Mau Mau From Within became a very invaluable guide as a man who had fought and lived alongside Kimathi, which gives them a completely different picture of the leader and the revolutionary war from what colonial writers had left behind in their works, like Henderson's The Hunt of Dedan Kimathi, Praxley's A Thing to Love, Ruark's Uhuru and Something of Value. Indeed, in their imaginative reconstruction of that episode of Kenya's history, in envisioning the world of the Mau Mau and Kimathi in terms of the peasants' and workers' struggle before and after constitutional independence, they have not shy from highlighting the role women played in the struggle:

[...] fearless determination and a spirit of daring is her character. She is versatile and full of energy in her responses to different roles and situations. A mother, a fighter, all in one. [...] she walks not exactly stealthily, but with great care - as if she treads on treacherous ground. She walks straight into the mouth of a gun (Ngugi \& Mugo, 1976: ii).

In their rewriting perspective, they counter Kimathi's portrait as a 'mentally unbalanced' and 'vicious' person which, according to them, constitute a biased and false one. However, they refrain from recreating the trial in a realistic way. They rather provide the reader with a tightly intertwined dramatic narrative, with a plot encompassing disparate but thematically interconnected episodes.

Therefore, the scenes in the courtroom where Dedan Kimathi's trial takes place are mingled with others that revisit some episodes derided from Kenya's history with a view to debunking the British colonialists' deliberated falsehoods, casting off Kenya's legacy of oppression and building up a new historia and memoria. The portrait presents Dedan Kimathi as a man of honor, loyalty, of courage, and commitment as seen by many of the peasants and workers of Kenya for whom he was risking his life in order to redress the relationship between history and memory. Like JeanClaude Schmidt (2002) for whom "thanks to memory, the past becomes images," (Ngugi \& Mugo, 1976: ii) and considering the active and dynamic relationship between images and memory, while showing that naming is political, Ngugi-Mugo's drama bears witness to the transformative effect of conversion and edifies a new orthodoxy that goes counter the British perspective that was foregrounded falsehood. Renaming aims at erasing memories of Kenyan history by renaming the Mau Mau revolution and their leader Dedan Kimathi:

[...] Above all, he loved people, and he loved his country. He so hated the sight of Africans killing one another that sometime became a little softe with our enmies [...]. He, Great commander that he was, Great organizer that he was, Great fearless fighter that he was, he was human! [almost savagely, bitterly]: too human at times! [13].

Ngugi and Mugo's drama raises awareness and revisits history in its portrayal of a true folk hero whose life and death are being made meaningful in contemporary Kenya. It is in the 'Nyandarua Forest' as one of the play's settings that they undertake their rehabilitation perspective of Dedan Kimathi's good deeds, personality, courage, vision, and humanity. They also show Woman's dialogue with Boy and Girl, an act which serves to re-introduce the guerilla leader as an important historical figure and the outstanding role played by women in the struggle. The shift to the Forest uncovers the historical qualities which have enabled him to be aware of the British colonial and neocolonial agenda as well as the 
need to mold a resistance strategy against it amid difficulty in retaining his own kinsmen. Rwimbo Rwa Kimathi, the song of Kimathi sung by the guerillas celebrates courage and inspiration with which he has initiated the revolution

Moreover, the plot of the play is closely knit with reconstructing the heroic struggle and Kimathi's PanAfricanist vision. It recaptures his strength and versatility, and enhances the need to humanize him so that Boy and Girl (representing African sons and daughters) can be aware of the urgency of their missions and the challenges to take up. It recalls Kimathi's trial at Nyeri which started on 18 November 1956 after being captured with 'unlawful possession of revolver and some rounds of ammunition,' which was, according to the colonial law, a capital offence under the 1952 Emergency laws. He was sentenced to death on 27 November and hanged to death and buried in Kamiti Prison:

Dedan Kimathi s/o Wachiuri, alias Prime Minister or Field Marshal, of no fixed address, you are charged that on the night of Sunday, October the $21^{\text {st }}, 1956$, at or near Ihururu in Nyeri District, you were found in possession of a fireman, namely a revolver, without a licence, contrary to section 89 of the penal code, which under Special Emergency Regulations constitutes a criminal offence. Guilty or not guilty? (Ngugi \& Mugo, 1976: 62).

Not only does Judge Shaw Henderson name and misname him (Prime Minister or Field Marshall), but he also ironically refuses him his Kenyan citizenship and identity as someone with no fixed address. However, the core objective of the play is not to unearth the detailed legalistic process, but more with displaying how Kimathi undergoes four 'trials' aimed at essentially breaking his commitment and resolve. In the first of these, the symbolically multi-purpose British official Shaw Henderson, who acts as a Judge and Prosecutor, and bears the surname of the policeman who has captured the real Kimathi, offers the guerilla hero his life in exchange for a confession which would end up the upheavals:

Dedan Kimathi: you must plead. Life comes before pride. You once vowed that no Whiteman would ever get you. But now you are in custody. Hanging between life and death. Plead, plead, plead guilty. It's a game, yes. You can name your price. You'll have your life. Only we must end this strife. Plead guilty for life (Ngugi \& Mugo, 1976: 3).

In his attempt to bribe and humiliate him, the British official draws the straightforward opposition between indigenous rebellion and various forms of colonialism military, judicial, and collaborationists. Despite Kimathi's sacrifice to snatch and restore Kenyans' dignity and freedom, the two playwrights have never understood some people's reticence about the heroes and heroines who stood up against the imperial regime in Kenya. The play's tone expresses the co-authors' regretful feeling over the absence of Kimathi and his associated guerilla leaders in the memoria of the Kenyan masses.

However, Ngugi and Mugo's heroism is an extreme form of prosociality, a category of behavior that involves benefiting another (Ngugi \& Mugo, 1976: 3). Theirs, of "typical prosociality nature, involves the actor delivering avenge - or expected - levels of benefits to others. Their hero Kimathi incurs costs involving risk of injury or death; or significant sacrifices such as time, money, or other forms of personal loss to deliver greater than expected benefit to others (Ngugi \& Mugo, 1976: 62). He engages in behaviors of a given cost as he delivers many more benefits to others. Typically these costs are incurred by him without certainly and/or negotiated expectation of direct future reward, (Ngugi \& Mugo, 1976: 35) but only a good memoria to refer to aspect involving memory in Western classical rhetoric. The two playwrights' analysis of herocism and martyrdom imaginary culminates the miniatures of the martyrs' heroism which are repeatedly reduced to a singular summation of their ultimate sacrifice. Kimathi and his men are portrayed in the midst of their passion: regaining freedom. These gothic illuminations reflect a long-standing devotional function to elite from the viewer a memorable vision of the martyr's triumphant torment and generate an empathetic simulacrum. Easton [14] explains how the violence in the legenda encourages affectively piety by facilitating mnemonic processes. The Gothic viewer simultaneously cultivates a personal devotional memory and actively participates in the hero's commemoration. The co-authors' method of iconological deduction is intertwined with a post-modern theoretical investigation of the body as a site of spectacle, a concept that crystallizes in the work of Elaine Scarry [15]. For them, the politics of renaming is, then, rooted in the nationalization of heritage. It misses the complex ways the British were actively engaged in fashioning what is now considered 'national heritage' through a refashioning of historical memories about Dedan Kimathi and his combatants. In their history reconstruction perspective, Ngugi and Mugo further use factual stories and conflicting legends about this great fighter. One of the first is that it has been assumed that he fought in the Second World War, making some people state that that was where he learnt his military and guns-making skills. They have proven that Kimathi never fought in that war; he evolved his brilliant guerilla tactics and his enormous organizing capacity from the needs of the struggle. Even if he is named a 'terrorist' in the British archive, Karunaini people are still proud of their son since they talk of him as a dedicated teacher, the committed organizer of theater group, as a man with tremendous sense of humor who could keep a whole house roaring with laughter. They also "talked of his warm personality and his love of people. He was clearly their beloved son, their respected leader and they talked of him as still being alive" [16]. His humanity spirit is emphasized here, which opposes the bloodthirsty monster portrayal in the British archives.

Moreover, Ngugi and his co-author cast off the imposed silence and reticence on the part of those who experience the pangs of neo/colonization by demonstrating, how much the British colonialists have moved into the ultimate 'hypermemory' phase of the memory syndrome in a bid to uncover a more complex story behind the perceived silence of 
Britain's colonial past. They trace out the two entwined trajectories of popular memories that emerged out of Dedan Kimathi's political commitment and re-establish the truth about the apparent surge in the outflow of first-hand narratives from the Kenyan and British sides alongside growing public interest in the Kenyan past follows on the heels of a long and active engagement with memory making. The two playwrights are aware of the need to 'decolonize' the Mau Mau revolution and Dedan Kimathi popular memories by identifying the processes through which activist members of each group have tailored or are made to tailor particular accounts about their respective pasts in order to maintain the integrity and survival of their communities and their unique identities. Kimathi himself underscores the sense of his struggle at the guerilla camp, the 'Nyandarua Forest,' when addressing the two 'Queen solders' fighting on the side of the British, arguing:

It's always the same story. Poor men sent to die so that parasites might live in paradise with ill-gotten wealth. Know that we are not fighting against the British people. We are fighting against British colonialism and imperialists robbers of our land, our factories, our wealth. Will you denounce British imperialism? (Allision, Goethals \& Kramer, 2016: 37).

The British have not been, then, objective in framing the history and memories of a whole country. As Claire Eldridge (2018) confirms it, "memory making is strategic, a conscious commemorative strategy based upon the reiteration of key propositions relating to a mythologized past" (Allision, Goethals \& Kramer, 2016: 37). In the play, Kimathi has overcome all the trials of doubt and weakness by reasserting his refusal to surrender and let foreigners exploit the country. The visionary ideologue and poet, as he is qualified, has stood up against the contending forces of the dominating imperialists, with their tricks and deceit and the redemptive violence of the dominated peasants and workers which the Ngugi and Mugo's drama has brought to the surface. Though the British exploiting forces do everything they can to perpetuate their hold on the exploited Kenyan masses, the guerilla leader and his fellow committed revolutionists have hazarded their lives for justice and self-determination as shown metaphorically through the voice of the character Girl:

I'm $[\ldots]$ tired $[\ldots]$ of $[. .$.$] running. All my life I have been$ running. On the run. On the road. Men molesting me. I was once a dutiful daughter. A nice Christian home. It was in the settled area [...] I ran away from school because the headmaster wanted to do wicked things with me. Always you remain behind [...] (Ngugi \& Mugo, 1976: iii).

Girl reasserts here the challenges which produce an anticipated fulfillment both in the world of the play and in the socio-economic milieu. So, neither the revolutionists nor the compradors of the ruling powers are romanticized as the scenes are to shift from the courtroom, the street, the cell, and the guerrilla camp, which denotes the 'four' trials Kimathi has gone through in the play. Ngugi and Mugo challenge that by delineating the boundaries of what [we] mean by memory and keeping the discussion centered on the key agents of memory making, the workers and the peasants for whom Kimathi was fighting. They believe that memories are always embodied and situated, so that what is remembered is understood in relation to who articulate them and for what purpose. They further evidence that these are products of a complex social process whereby the Kenyan populations who have lived through trauma constantly search for meaning by looking to communally (re)configured narratives relevant to their individual memories. They break the same kind of patron-client relations that was and is still historically characteristic of politics in post/colonial Kenya. In their memoria reframing, they uncover that which remain in the shadows of official commemorations and read the nationstate-centric narratives that have dominated for so long memories about the Mau Mau struggle and their leader Dedan Kimathi as 'sadly' and 'contemplatively' countered by Woman:

It is true children, that Kimathi could do many things. Even today, they sing of the battle of Mithari; the battles he waged in Mount Kenya; the battle of Niavasha. Yes, they sing of the enemy aeroplanes he brought down with only a rifle! He was a wonderful teacher: with a laugh that was truly infectious. [...] a story teller too, and may were the nights he could calm his men and make their hearts light and gay with humorous anecdotes! (Ngugi \& Mugo, 1976: 64).

Through the voice of Woman, Ngugi and Mugo emphasize the memory of sacrifice, thereby limiting the ways the Kenyan community could be coopted for causes beyond those they promoted. Debates about Britain's Kenyan past had inevitably given way to more and more conflicting perspectives and memories with the uncovering of such sensitive and taboo topics as torture, violence, and murder inflicted on Kenyan nationalists have aggravated the authors' eagerness to erect a more redeeming story about their life in the 'Nyandarua Forest' and the trauma they have suffered during the upheaval.

Therefore, the two playwrights (re)presented Kimathi to the world as a prototypical hero characterized by physical feats, bravery, and high risk of serious injury and death, as a war hero who has saved his people from peril (colonialism and neocolonialism). As such, the 'Nyandarua Forest' scene, in which the arrested British soldiers are being tried, is juxtaposed with the British courtroom one, where Judge Shaw Henderson is eager to take the condemning charge against Kimathi to its legal end. He knows that he will never ever confess and there is for this purpose no need wasting time with him. Consequently, his logical end becomes sentencing him to death as a way of muffling the struggle. It is at this level that Ngugi and Mugo make a quick movement of physical and symbolic intrusion into the functioning of imperialist methods as Judge Shaw Henderson goes on to pronounce the sentence. In that, Woman, disguised as a lady enters the courtroom, reassures Kimathi in chains, followed by Boy and Girl, as a way of making him convinced that the commitment to the cause of freedom is and will be alive forever. 


\section{Weaving (Hi)story and Ideology: Breaking the Psychological and Economic Bondage of the Neo/Colonial Periods}

Ideology, as posited by Cayne et al, is a body of ideas used in support of an economic, political or social theory; the way of thinking of a class, culture or individual. Ideologically, Ngugi and Mugo are of the view that good theater is that which is on the side of the people [...] gives people courage and urges them to higher resolve in their struggle for total liberation. This is the reason why the first movement of The Trial of Dedan Kimathi (1976) is much telling of how the two playwrights weave (hi)story and ideology to break the psychological and economic bondage of the colonial and neocolonial periods. They use taxonomy, from Greek taxis, to account for the arrangement or division, and nomos, meaning law (two laws, one for the rich and another for the subalterns), and for the colonial classification according to a predetermined system, with the resulting catalog used to provide a conceptual framework for discussion, analysis or information retrieval. In theory, the development of a good taxonomic classification takes into account the importance of separating elements of a group into subgroups (the Mau Mau fighters and their supporters and those who do not back the guerilla, but defend colonialism, e.g., the K. A. R soldiers) that are mutually exclusive and unambiguous, and taken together, include all possibilities. This procedure, then, shows a Kenyan colonized society that is pauperized and discriminated against. As the plays unfolds, they combine songs and dance and the effect of soft light of the history of the Kenyan people to recall the different phases and rhythms of exploitation, subjugation, slavery, and cruelty to the contemporary era of anti-imperialist resistant protest. It also shows political clashes between the forces of the settlers and the guerilla and its leader Dedan Kimathi. The two playwrights use a sub-plot that introduces Boy and Girl and describes them in their rustic simplicity, immaturity, and state of unconsciousness. It is through the encounter with Woman that the former gradually acquires the mental state of selfrealization that will permit him in the last movement to gain a more realistic and more empowering perception of reality and the side effects of British presence in Kenya. This is evidenced by the omnipresent voice of Woman who argues that 'the day you'II ask yourself [...] what can I do that another shall not die under such grisly circumstances [...] that day you will become a man, my son" [17]. The idea, then, throws light on Kenya's socio-economic situation which is characterized by general misery and widespread prevalence social inequalities, unemployment, and poverty as Woman recalls:

Nagi! It is the same old story. Everywhere. Mombasa. Nakura. Kisumu. Eldoret. The same old story. Our people $[\ldots]$ tearing one another $[\ldots]$ and all because of the crumbs thrown at them by the exploiting foreigners. Our own food eaten and leftovers" (Lonsdale, 1997: 27).
Ngugi and Mugo engage in a theater of consciousnessraising and encouragement to fight. They dramatize the Kenyan masses in their resistance and resilience to colonial torture, ruthless oppression as well as their continued determination to end exploitation and new forms enslavement. Positing that the artists in the traditional African milieu speak for, and on behalf of their community, around the history of Kimathi, they seek to mobilize popular will against neo/colonialism and the new capitalism system which were and are still widening the gap between the rich and the poor.

The co-authors recall Kimathi-led Mau Mau guerilla's motto that revolves around "Unite, drive out the enemy and control your own riches, enjoy the fruit of your sweat" (Lonsdale, 1997: 62). They display African experiences, whose ideological values and mores are fashioned by their every day misfortunes. In fact, in the play, the protagonist Dedan Kimathi embarks on a long discursive struggle with Judge and Prosecutor Shaw Henderson about how to refer to the Mau Mau revolution. So, rhetoric becomes a key element in the interactions of the two characters, each of whom represents the interests of his own community. Like Aristotle, who considers rhetoric a counterpart of both logic and politics, and calls it "the faculty of observing in any given case the available means of persuasion (Lonsdale, 1997: 22), Ngugi and Mugo's resort to means typically provides heuristics for understanding, discovering, and developing arguments for particular situations. They lean on Aristotle's three persuasive audience appeals that are logos, pathos, and ethos. To turn the unspeakable into speakable, the two playwrights further use the dialectic-dialogism and dialogicdialectic perspectives (Lonsdale, 1997: 27), whose use in the play's different tones, interaction, and contradiction are essential to its interpretation. In this discursive struggle, they re-introduce to the reader the literature of silence as a misnomer. They make Dedan Kimathi remain silent when Judge Shaw Henderson proffers the charges against him and later warns him that "your silence could be constructed as contempt of court, in which case I could order that you be sent for a certain term to jail" (Lonsdale, 1997: 18). His silence accounts for the playwrights' violation of the canons of drama writing and imperial logics. Kimathi's silence bears, then, a metaphysical paradox insofar as it is meant to serve both as an aesthetic system for Ngugi and Mugo and a creative challenge for the Kenyan masses. The guerilla leader's attitude is obviously that of contempt for the imperial system which marks a movement that seeks to go beyond the bounds of logic and the limits of language, that transcends the language of reason and to give birth to songs and dancing, as expressions of anti-colonialism. In Kimathi's mind, an absence of speech does not necessary proffer an absence of naming and renaming. In this process, what Ngugi and Mugo and their hero do not reveal carries more interpretative weight than what they do. Textual and societal silence resists any authoritarian impulse fixing meaning, they invite the reader to read between the lines and give choices to the silent underpinnings of the Kenya masses and writers. For 
this reason, one must consider not only what is articulated (the speakable) but also what is suggested through silence or not articulated (the unspeakable) via the politics of secrecy and silence. Silence and silencing become, then, modes of expression for Kimathi in a context where official discourse has attempted to dictate meaning and where fear injustices have informed his leadership as a freedom fighter, many times silence, gaps, half-informed utterances or supposed experiences or expressions of horror speak most authentically to the experience of state 'eco-terrorism': colonialism and neocolonialism. Just as an abundance of words is associated with, meaning or mismeaning does not always lead to greater understanding, in Kimathi's mind, the rhetoric of silence operates as an expression of past and present imperial horrors. In the context of Ngugi-Mugo drama's expression, silence becomes an effective tool of resistance and answer insofar as it informs the essentialization of memory and forgetting.

Moreover, Ngugi and Mugo use realistic dialogue to express their disgust and bitterness at how the legitimate Kenyan masses have been deprived of their means of production by a white colonial minority. The ideological differences between the two groups has led to Kimathi's spirit of revolution like the one embodied by Danlola in Kongi's Harvest (Lonsdale, 1997: 18). In the second trial, a politician and some members of the African and Asian middle class are sent to talk him with visions of material wealth into surrendering:

Confess. Repent. Plead guilty. Co-operate like the surrendered generals. Tell your people to come out of the Forest. We need stability. There never can be progress without stability. Then we can finance big Hotels, International Hotels, seaside resorts Night Clubs Casinos Tarmac roads Oil refineries and pipeline. Then tourist from USA, Germany, France, Switzerland, Japan will flock in. Investment, my friend, development, prosperity, happiness [18].

Kimathi pinpoints the difference in meaning when it comes to development which he ironically terms "partnership in progress" [19]. He also refutes the coloniality of being, of knowledge, and power, asking the black politician to tell him what colonization has done to his thinking to an extent that he promotes "independence for Central Province and later followed by Gikuyu, Embu and Meru who really fought for Uhuru" (Ngugi \& Mugo, 1976: 3). He does not see eye to eye with his fellow countryman who is on the side of the colonizer in that, for him, "Kenya is one indivisible whole. The cause we fight for is larger than province" [20]. For Kimathi money does not make development in the colonial context in which 'progress' is brandished. But for him, the questions that should be asked are twofold: whose development? And for whom? The Banker insists that it is Kimathi's ten-year-armed resistance that has thwarted the chances of 'progress.' Further, when talking to the Indian who gives him an unfair and unrealistic description of postindependent India as a prosperous country, Kimathi reminds him that "they told of hungry peoples, beggars on pavements $[\ldots]$ wives selling themselves for a rupee [...] have they now said “no" to poverty?" (Ngugi \& Mugo, 1976: 40). He realizes that his people are not taken into account in their politics of development, those he refers to as the oppressed of the land [...] all those whose labor power has transformed this land. For, it is not true that it was their money that built the country. It was theirs, their sweat, their hands, challenging him to tell him where his people come in their 'partnership for progress,' and vetoing on the ground the servants-masters and sellers-buyers of labor paradigms. For him, this "makes the colonized sweat and bleed while master comes to harvest" (Ngugi \& Mugo, 1976: 47). In the third trial, a politician and a former and now turned-'radical' successful businessman are sent to glorify the neocolonial policies and promise him "no more racialism, no more color bar in public places [...] that's the new motto [...] we can now buy land in the White Highlands" (Ngugi \& Mugo, 1976: 46), which compels him to harshly call them to order, exclaiming "buy back our land from those who stole it from us?" (Ngugi \& Mugo, 1976: 46). In the fourth one, taking note of Kimathi's note of defiance and resilience but also of hope, Judge Shaw Henderson grows weary and decides to stop his 'hypocritical' politics of persuasion and resort to torture so as to have him signed a letter calling on the Mau Mau freedom fighters stationed at the 'Nyandarua Forest' to surrender.

Indeed, Kimathi's use of memory in his different encounters with the representatives of the imperial apparatus (Politician, Banker, Businessman, Indian, etc.) has affected how his oratory has influenced the reader and the court's audience. It is through these dialectical and dialogical interactions, relying solely on his memory, that he builds a certain amount of ethos within the relationship (Ngugi \& Mugo, 1976: 39). Kimathi's (re)constructed memoria in relation to ethos during his dialogue describes the sentiment of trustworthiness felt between the court's audience, the reader, and himself, as well as the level of similarity, authority, and expertise as an orator, a historian, and a knower, he has over the audience as he lays bare what he terms:

The visible powers behind them all. So smooth, so confident, heartless, soulless, Banker Industrialist Settler Governor Police Army Judge all one. Drinkers of Darkness. Drinkers of blood. Ha! Ha! Why should I fear? Our people will see through the smiles, through this sudden avowal of friendship. And yet suppose it if save my life? No...Dreams Temptations People [shouts]: Our people! (Ngugi \& Mugo, 1976: 40).

He further responds to Judge Shaw Henderson who reminds him of how "we used to play together as children, on the slopes of Mount Kenya? Remember the day we played Horse and Rider? (Ngugi \& Mugo, 1976: 45). For the latter, there has to be a horse (a dominated) and a rider (a dominant). But for the former, time has come for the rules of the 'game' to change, now suggesting that since "there must be horses and riders [...] well let me be Balaam's ass then [...] the one who rejected his rider. When the hunted has truly learnt to haunt his hunter, then the hunting game will be 
no more" (Ngugi \& Mugo, 1976: 45). So, for Kimathi, only imperialist arrogance can imagine what Africans want, determine they need, and devise ways to deliver the goods as a way of looking at the subject position of black people which encompasses themes of alienation and aspirations for a utopic future: Afrofuturism for an Afrofuturist ideal. This is one of the reasons why he despises "your laws and your courts. What have they done for our people? What? Protected the oppressor. Licenced the murderers of the people: Our people, whipped when they did not pick your tea leaves" [21]. Moreover, for the co-authors, the relevance and indispensability of the West in African affairs thrives in the availability of problems and crises.

\section{Conclusion}

After being subjected to marginalization and silence for many years, Ngugi and Mugo have deliberately decided to end the result of decades of selective memory making as the failure to control history. They have written The Trial of Dedan Kimathi (1976) in their endeavor to provide [us] with a fuller understanding of the evolution in the postcolonial terrain of memories and by extension, the terrain of identities in Kenyan society. The two playwrights have shown, in fact, how censorship, through the politics of naming, misnaming, and renaming as an imposition of silence on others and their histories, stories, and memories have worked in different ways during the Mau Mau revolution. This is one of the strategies used by the colonizers to downplay all aspects of the struggle and its leader Dedan Kimathi. Ngugi and Mugo's drama belongs to a theater of consciousness-raising and encouragement to struggle that seeks to memorialize this part of Kenyan history. It also looks to mobilize popular will against the economic deprivation that the country's masses were made to endure, to feel outsiders in their own homeland, and become alienated as a result of the discriminatory policies set up the British colonizers. To them, that was degrading and dehumanizing insofar as the land was rightfully for the Kenyans. So, in failing to address and to create a system through which African grievances against British settlers could be settled fairly, the Kikuyu grew more dissatisfied with the colonial administration failures. Among the grievances, as pinpointed by Ngugi and Mugo, there has been also the creation of a hierarchy of victimhood and perpetrators through the implementation of a 'two justices, two laws' policy.

Indeed, the two playwrights have uncovered Kimathi's ideology, vision, and life philosophy through the voice talking to Boy, underscoring the need to stand up and end Kenyans' complaints about forced labor, low wages, heavy taxation, continuing land alienation, and racial discrimination. They have proven that in a conflict there are two sides in opposition to one another, and that a person who is not actively committed to one side must be supporting the other. In a course of a conflict, leaders on both sides use this argument to gain active support from the 'crowd.' In reality, conflicts involving more than two persons usually have more than two sides, and if a resistance movement is to be successful or to fail, propaganda and politicization are necessary mechanism. However, ideologically, in the play, Ngugi and Mugo have insisted on unity for a common stand against imperialism (neo-slavery, neocolonization, globalization, and exploitation) as a prerequisite to any freedom as shown metaphorically in the last scene of the play in which people get together, sing, and dance in chorus.

\section{References}

[1] Wunyabari O. Maloba (1993), Mau Mau and Kenya: An Analysis of a Peasant Revolt (Oxford: James Currey, p. 7.

[2] David Anderson (2005), Histories of the Hanged: The Dirty War in Kenya and the End of Empire, New York and London: W. W. Norton \& Company, p. 10.

[3] David Anderson (2005), Histories of the Hanged: The Dirty War in Kenya and the End of Empire, op. cit., p. 10.

[4] Caroline Elkins (2005) Imperial Reckoning: The Untold Story of Britain's Gulag in Kenya, Henry Holt and Company, p. 294.

[5] Kenneth Watene (1974), Dedan Kimathi, Nairobi, Transafrica Publishers.

[6] Jean-Claude Schmidt (2002), Le Corps des images. Essais sur la culture visuelle du Moyen Âge, Paris, Gallimard, p. 18.

[7] Ngugi wa Thiong'o \& MIcere Githae Mugo (1976), The Trial of Dedan Kimathi, African Publishing Group, p. i.

[8] Tabitha M. Kanogo (1992), Dedan Kimathi: A Biography, Volume 3 of Makers of Kenya's history, East African Educational Publishers, p. 23.

[9] Fred Majdalany (1963), State of Emergency: The Full Story of Mau Mau, California Houghton Mifflin..

[10] Josiah Muwangi Kariuki (1960), "Mau Mau" Detainee: The Account by a Kenya African of His Experiences in Detention Camps, 1953-1960," The International Journal of African Historical Studies, Volume 9, Africana Publishing Company, p. 167.

[11] Franck Furedi (1989), The Mau Mau War in Perspective, Ohio University Press.

[12] Marshall S. Clough (1998), Mau Mau Memoirs: History, Memory and Politics, op. cit., p. 24

[13] John Lonsdale (1997), 'Foreword' in “Kershaw, G., Mau Mau

[14] Jacques Derrida (1997), Of Grammatology (Baltimore \& London: Johns Hopkins University Press, 1997, corrected edition, trans. Gayatri Chakravorty Spivak).

[15] Jean-Claude Schmidt (2002), Le Corps des images. Essais sur la culture visuelle du Moyen Âge, op. cit., p. 19.

[16] Scott T. Allison, George R. Goethals \& Roderick M. Kramer (2016), Handbook of Heroism and Heroic Leadership, New York \& London, Routledge, p. 37.

[17] Elma Brenner \& Meredith Cohen \& Mary Franklin-Brown (2013), Memory and Commemoration in Medieval Culture, http://www.history.ac.uk/reviews/review/1601, accessed May 21, 2018 
[18] Elaine Scarry (1985), the Body in Pain: The Making and Unmaking of the World, Oxford University Press, p. 7.

[19] Claire Eldridge (2018), From Empire to Exile: History and Memory Within the Pied-Noir and Harki, London, Oxford University Press, p. 128.

[20] Thomas Conley (1991), Rhetoric in the European Tradition, University of Chicago.
[21] Kon Klancher (1988), "Bakhtin's Rhetoric," Landmark Essays on Bakhtin, Rhetoric, and Writing. Ed. Frank Farmer. Mahwah: Hermagoras Press, 23-32. 